\title{
ANTARA AKU, JODOHKU DAN AKUNTANSI
}

\author{
Selvia Eka Aristantia, Ade Irma Suryani Lating \\ Fakultas Ekonomi dan Bisnis Islam, Universitas Islam Negeri Sunan Ampel \\ e-mail: selviaekaaristantia@gmail.com
}

\begin{abstract}
Although accounting has an important role in married life, it turns out there are many millennials who have never delved into the beauty of the ocean of marriage but are also interested in studying accounting and its branches. It is not even taboo nowadays to consider accounting knowledge or financial management capabilities possessed by a potential partner as one of the criteria besides the other criteria that are dreamed of. Therefore, the author wanted to examine how the meaning of accounting in building domestic life. Researchers used a phenomenological approach in the search for meaning both explicit and implied.
\end{abstract}

Keywords : behavioral accounting; mental accounting; household accounting, phenomenological approach

\begin{abstract}
ABSTRAK
Meski akuntansi memiliki peran penting dalam kehidupan berumah tangga, ternyata banyak generasi milenial yang belum pernah mendalami indahnya samudra pernikahan namun juga tertarik untuk menekuni ilmu akuntansi dan cabang-cabangnya. Tidaklah tabu lagi untuk mempertimbangkan pengetahuan akuntansi atau kemampuan manajemen keuangan yang dimiliki oleh calon mitra sebagai salah satu kriteria disamping kriteria lain yang diimpikan. Oleh karena itu penulis ingin mengkaji bagaimana pengertian akuntansi dalam membangun kehidupan rumah tangga. Peneliti menggunakan pendekatan fenomenologis dalam mencari makna baik tersurat maupun tersirat.
\end{abstract}

Kata Kunci : akuntansi keperilakuan; mental accounting; household accounting, pendekatan fenomenolog

\section{PENDAHULUAN}

Akuntansi sebagai bagian dari ilmu sosial merupakan ilmu aplikatif yang sarat nilai. Tidak hanya deretan angka diatas buku besar. Tidak hanya barisan nominal dalam laporan keuangan tanpa makna. Namun tanpa kita sadari, akuntansi telah menjadi ilmu yang menjadi bagian penting dari kehidupan kita. Sadar atau tidak dalam keseharian, kita telah menginternalisasi akuntansi keperilakuan dalam beberapa aktivitas pengambilan keputusan. Akuntansi keperilakuan merupakan perilaku-perilaku yang membawa individu dalam keputusan-keputusan akuntansi ataupun sebaliknya yakni akuntansi membawa individu kedalam perilaku-perilaku tertentu.

Seringkali kita menempatkan posisi dalam suatu pilihan yang membawa kita dalam keputusan-keputusan akuntansi. Contohnya adalah ketika kita lebih memilih berbelanja di toko A yang berjarak 50meter lebih jauh dari rumah daripada berbelanja di toko B yang lokasinya lebih dekat. Alasannya karena di toko A menjual barang yang lebih murah dibandingkan dengan toko B. Contoh lainnya adalah ketika kita lebih memilih untuk membeli AC dengan watt yang lebih kecil demi menghemat biaya listrik atau membuat keputusan untuk tidak menyalakan air terus menerus saat mencuci tangan ataupun saat mencuci piring demi menghemat tagihan air. Sadar atau tidak kita telah menjadi praktisi dari disiplin ilmu akuntansi ini.

Akuntansi telah menjadi kebutuhan bagi semua orang. Ya, semua orang. Baik yang tua ataupun yang muda, yang kecil ataupun dewasa baik yang miskin maupun yang kaya. Masingmasing individu pasti pernah mengalami menjadi praktisi akuntansi. Tidak harus dengan bekerja menjadi akuntan ataupun menjadi mahasiswa akuntansi. Setidaknya kita pasti akan menjadi seorang akuntan untuk diri sendiri dan menjalani kebiasaan-kebiasaan tertentu yang berbeda antara satu individu dengan individu yang lainnya hingga membentuk suatu mental accounting. Mental Accounting merupakan suatu keterampilan untuk 
p-ISSN 1693-1378

e-ISSN 2598-9952

menalar logika yang digunakan oleh individu dan rumah tangga dalam mengatur, mengevaluasi, dan melacak kegiatan keuangan (Thaler, 1999). Individu dan rumah tangga merupakan bagian sistem terkecil dan paling sederhana dalam penerapan akuntansi.

Di Indonesia, penelitian akuntansi mengenai household accounting atau penerapan akuntansi dalam rumah tangga tergolong lebih sedikit diminati dibandingkan dengan penelitian akuntansi dalam suatu corporate atau pemerintahan. Hal ini dapat dilihat dari jumlah penelitian mengenai akuntansi rumah tangga yang tidak begitu banyak dilakukan dibandingkan dengan penelitian dalam lingkup yang lebih besar seperti akuntansi di suatu perusahaan. Padahal menurut peneliti, justru di lingkup terkecil inilah dapat dipelajari bagaimana terbentuknya akuntan handal dan dapat pula tercermin nilai-nilai serta etika akuntan sesungguhnya dengan lebih natural karena terimplentasi dalam keseharian.

Pengetahuan mengenai akuntansi ataupun pengelolaan keuangan saat ini bukan merupakan teori yang hanya dilahap untuk para akademisi saja atau hanya merupakan suatu praktik yang dapat diimplementasikan oleh para praktisi. Setiap individu dapat mengimplementasi akuntansi dengan cara-cara tertentu yang dipahaminya dan sesuai dengan kebutuhannya. Teknologi yang mumpuni saat ini juga menjadikan akses ilmu pengetahuan lebih mudah untuk didapat oleh siapa saja dan dimana saja. Sehingga jika ada kemauan, setiap orang dapat mempelajari lintas disiplin ilmu diluar studi yang ditekuni. Apalagi di masa pandemi covid-19 seperti sekarang ini, banyak sekali bertebaran seminar daring yang membahas berbagai macam bidang, salah satunya adalah pengetahuan mengenai akuntansi dan keuangan. Melalui bermacam-macam media pembelajaran menjadikan ilmu Akuntansi semakin eksis dan dapat dipelajari oleh siapapun dan untuk keperluan masing-masing pribadi.

Saat ini juga banyak media sosial yang memberikan konten-konten seputar akuntansi dan keuangan seperti twitter dan Instagram. Hal ini pun mendapat sambutan antusias dari warganet. Akun-akun tersebut banyak mengundang ketertarikan yang terbukti dengan banyaknya pengikut sebesar puluhan juta yang dominan merupakan kaum milenial. Hal tersebut menjadikan generasi milenial saat ini menjadi lebih 'aware' terhadap permasalahan akuntansi dan keuangan sehingga tertarik untuk mempelajari disiplin ilmu akuntansi lebih dalam dan akhirnya
Antara Aku, Jodohku dan Akuntansi (Selvia Eka Aristantin, Ade Irma Suryani Lating)

menjadi 'melek' akan masalah-masalah finansial. Mempelajari ilmu akuntansi ini penting bukan hanya sebagai bekal pengetahuan untuk pribadi namun juga sebagai bekal dalam mengarungi kehidupan rumah tangga. Seperti halnya mempelajari manajemen budgeting dalam rumah tangga, menyusun arus kas dalam rumah tangga ataupun mempelajari investasi masa depan yang berguna untuk menambah asset.

Akuntansi telah menjadi kebutuhan oleh semua orang termasuk dalam lingkup kecil seperti rumah tangga. Sama halnya dengan tujuan akuntansi dalam perusahaan. Individu dan rumah tangga juga memerlukan akuntansi untuk mencatat, meringkas, menganalisis dan melaporkan hasil transaksi dan peristiwa keuangan sehari-hari dalam format yang lebih sederhana. Individu dan rumah tangga menggunakan akuntansi untuk melacak dimana uang mereka berada dan kemana uang mereka pergi serta menjaga pengeluaran yang tidak terkendali dan Akuntansi mental mendeskripsikan cara individu melakukan hal-hal tersebut berdasarkan alasan-alasan tertentu (Thaler,1999). Hal ini berlaku pula bagi individu yang belum memiliki pasangan (Jomblo) dalam berumah tangga pasti memiliki alasan-alasan tertentu dalam mengambil keputusan-keputusan akuntansi.

Akuntansi mental dapat dipelajari dari keseharian individu. Tidak ada yang sumber pembelajaran yang setara dibandingkan dengan mengamati perilaku dan menyimpulkan aturan. Alasan utama untuk mempelajari akuntansi mental adalah untuk meningkatkan pemahaman kita tentang psikologi pilihan. Bagaimana cara seseorang mengambil keputusan-keputusan akuntansi diantara pilihan-pilihan yang ada (Thaler, 1999).

Rumah tangga harmonis dapat dibangun dari pengalaman dan pengetahuan dua manusia yang berbeda yang dipersatukan dalam satu atap. Dari satuan atap ini terlahir kokohnya nilai dan moral individu yang dapat membentuk suatu bangsa. Dan dari satuan atap ini, akuntansi yang sarat nilai dapat tercermin dalam kehidupan sehari-hari. Akuntansi memang tidak bebas pengaruhnya dari lingkungan bahkan sangat rentan terhadap watak lingkungan (Suharsono, 2020). Akuntansi diibaratkan bagai pedang bermata dua. Akuntansi dapat dibentuk oleh lingkungannya dan sekaligus dapat membentuk lingkungannya (Triyuwono, 2006). Oleh karena itu, akuntansi dapat digunakan untuk kebaikan maupun kejahatan dan dari individu maupun dari lingkup terkecil seperti 
rumah tangga, nilai akuntansi itu dapat terbentuk.

Ilmu Akuntansi juga dapat diibaratkan bak dewa eros atau dalam mitologi Yunani dipercaya sebagai dewa cinta, anak dari afrodit yakni dewa kecantikan. Hal tersebut lantaran ilmu Akuntansi ini memiliki kekuatan yakni mampu mempengaruhi hati dan pikiran manusia. Akuntansi dapat menguatkan cinta seorang manusia. Ada uang abang disayang. Namun Akuntansi juga dapat melemahkan cinta seorang manusia bahkan menjerumuskan manusia dalam kekelaman. Tidak ada uang abang ditendang. Dalam kasus yang lebih ekstrim, akuntansi dapat menyebabkan runtuhnya rumah tangga akibat perceraian (Jatmika, Lia dan Esti, 2018). Untuk menghindari hal-hal yang tidak diinginkan ini lah salah satu hal yang membuat orang ikut termotivasi dalam mempelajari disiplin ilmu akuntansi.

Meskipun ilmu akuntansi ini mempunyai peran penting dalam kehidupan berumah tangga, ternyata banyak pula jomblo yang juga tertarik untuk mempelajari ilmu akuntansi dan cabangcabangnya. Bahkan bukan hal yang tabu lagi di jaman sekarang untuk mempertimbangkan pengetahuan akuntansi ataupun kemampuan pengelolaan keuangan yang dimiliki oleh calon pasangan (jodoh) sebagai salah satu kriteria disamping bibit bebet bobot lain yang diimpikan. Hal ini menandakan setiap jomblo pun sadar atau tidak telah membawa mental accounting dalam setiap kriteria pilihan jodohnya. Oleh karena itu, penulis ingin meneliti bagaimana makna akuntansi dalam menetapkan kriteria jodoh untuk membangun kehidupan rumah tangga dengan menggunakan pendekatan fenomenologi dalam perjalanan pencarian makna baik yang tersurat maupun yang tersirat.

\section{METODE PENELITIAN}

Untuk memperoleh jawaban atas pertanyaan penelitian, setiap penelitian akan memiliki jalan pencarian yang tentu saja berbeda antara satu dengan yang lainnya. Dalam Penelitian ini, peneliti memilih metode penelitian kualitatif dengan paradigma interpretif. Penelitian kualitatif tentunya tidak bertujuan untuk meng-generalisir sesuatu namun lebih kepada pendekatan individu untuk memahami dan mendalami atas fenomena yang terjadi. Dari konsep fenomena ini dapat terdeskripsi pemaknaan atas pengalaman individu (Cresswell, 1998). Untuk membawa peneliti untuk terlibat dan memasuki sudut pandang dari objek yang diteliti, peneliti memilih untuk menggunakan pendekatan Fenomenologi Transendental.

Fenomenologi transsendental ini menegaskan keberadaan individu yang membedakan antara satu dengan yang lainnya karena pengalaman yang telah dialami oleh seorang individu akan membentuk persepsi, ingatan, ekspektasi dan imajinasi yang berbeda. Tujuan dari Fenomenologi Transendental adalah untuk memahami pengalaman individu dan bagaimana individu tersebut memahami makna atas suatu hal (Husserl, 2006). Meskipun peneliti mengambil informan dengan latar belakang yang berbeda, fokus penelitian ini adalah tetap kepada pribadi individu tersebut. Sehingga peneliti dapat memberi penjelasan antara satu informan dengan informan lainnya yang memiliki pengalamanpengalaman yang berbeda.

Objek dari penelitian ini adalah fenomena terkait akuntansi sebagai salah satu dasar penetapan kriteria jodoh untuk membangun kehidupan rumah tangga. Subjek dalam penelitian ini dipilih sebanyak 2 (Dua) informan. Menurut kamayanti (2017), Tugas dari seorang fenomenolog adalah mengupas "aku" yang dengan sangat dalam jika fenomenologi benarbenar dilakukan. Oleh karenanya, 10 (Sepuluh) informan akan dirasa terlalu banyak. Untuk itu, dalam penelitian in, peneliti berfokus pada 2 (Dua) informan yakni pria dan wanita yang berstatus jomblo dengan latar belakang akuntansi dan non-akuntansi. Penelitian ini menggunakan jenis data primer yang diperoleh dari wawancara semi-terstruktur. Wawancara semi-terstruktur dipilih agar peneliti lebih fleksibel dalam memberikan daftar pertanyaan penelitian sehingga tercipta suasana kedekatan, dengan harapan informan dapat menjawab pertanyaan dengan nyaman karena topik yang dibahas adalah masalah sensitive yakni keuangan.

Wawancara dilakukan dengan media video teleconference zoom dengan merekam video percakapan dengan informan mengingat adanya pembatasan tatap muka oleh pemerintah akibat adanya pandemi covid-19. Sehingga peneliti senantiasa tetap menjalankan protokol physical distancing dengan tidak mengadakan pertemuan terjadwal untuk wawancara antara peneliti dengan para informan. Adanya perubahan mengenai cara peneliti melakukan wawancara penelitian menyesuaikan dengan kondisi dan perubahan yang ada. Hal ini tentu tidak mengurangi kualitas wawancara antara peneliti dengan informan. Justru kelebihannya, peneliti dapat menjangkau informan yang tengah berada di luar kota. 
Melakukan penelitian ini tentu saja menjadi sebuah pengalaman positif yang cukup menarik bagi peneliti untuk tetap produktif meneliti ditengah pandemi. Metode penelitian kualitatif
Antara Aku, Jodohku dan Akuntansi (Selvia Eka Aristantin, Ade Irma Suryani Lating)

Tabel 1

Daftar Informan

\begin{tabular}{cccccccc}
\hline No. & $\begin{array}{c}\text { Nama } \\
\text { Informan* }\end{array}$ & $\begin{array}{c}\text { Jenis } \\
\text { Kelamin }\end{array}$ & Usia & Status & Domisili & Pekerjaan & $\begin{array}{c}\text { Background } \\
\text { Pendidikan }\end{array}$ \\
\hline 1 & Tumi & Perempuan & 29 & Lajang & Magetan & Mahasiswa & Non-Akuntansi \\
\hline 2 & Mocha & Laki-laki & 28 & Lajang & Pasuruan & $\begin{array}{c}\text { Dosen } \\
\text { Akuntansi }\end{array}$ & Akuntansi \\
\hline
\end{tabular}

Sumber: data diolah

Dalam penelitian fenomenologi menekankan pada subjektifitas dan pengungkapan dari pengalaman dengan beberapa komponen konseptual (Putra dan Kamayanti, 2013). Tahapan fenomenologi berangkat dengan memetakan noema dan noesis, bukan sekedar wawancara. Noema dan noesis tersebut didapatkan dari hasil wawancara yang dianalisis lagi untuk menemukan makna sesungguhnya. Jika dianalogikan, fenomenologi seperti mengupas bawang. Setelah dilakukan wawancara, terdapat beberapa tahapan dalam penelitian fenomenologi transendental yang akan peneliti lalui. Tahapan pertama adalah epoche yang merupakan suatu proses penangguhan penilaian yang dilakukan oleh peneliti meskipun peneliti telah mendapat prakonsepsi terhadap fenomena makna penetapan pengetahuan akuntansi sebagai kriteria pasangan. Tahapan kedua ialah reduksi fenomenologi. Dalam tahapan ini, peneliti menangkap ungkapan atau ekspresi yang dilakukan oleh subjek penelitian.

Tahapan ketiga yang dilakukan oleh peneliti adalah variasi imajinasi yakni peneliti mencari makna dengan mengandalkan imajinasi peneliti. Tujuan dari pemanfaatan imajinasi peneliti adalah untuk menghasilkan deskripsi structural dari sebuah pengalaman dan pada akhirnya peneliti dapat menemukan makna murni yang dipengaruhi oleh intuisi peneliti. Langkah terakhir adalah sintesa makna. Dalam tahap ini, peneliti membangun keseluruhan deskripsi dari sebuah fenomena atau peristiwa yang terjadi (Husserl : 1983).

Setelah tahapan penelitian yang telah disebutkan, peneliti juga melakukan triangulasi data yakni, yang pertama adalah reduksi data. nantinya pasti akan terus berkembang menyesuaikan dengan perubahan-perubahan yang ada.
Peneliti memilih dan memusatkan perhatian terhadap transformasi data kasar yang diperoleh dari catatan-catatan kasar selama tahap wawancara. Proses yang kedua ialah penyajian data setelah proses seleksi dan meringkas. Proses terakhir yakni dilakukan penarikan kesimpulan makna.

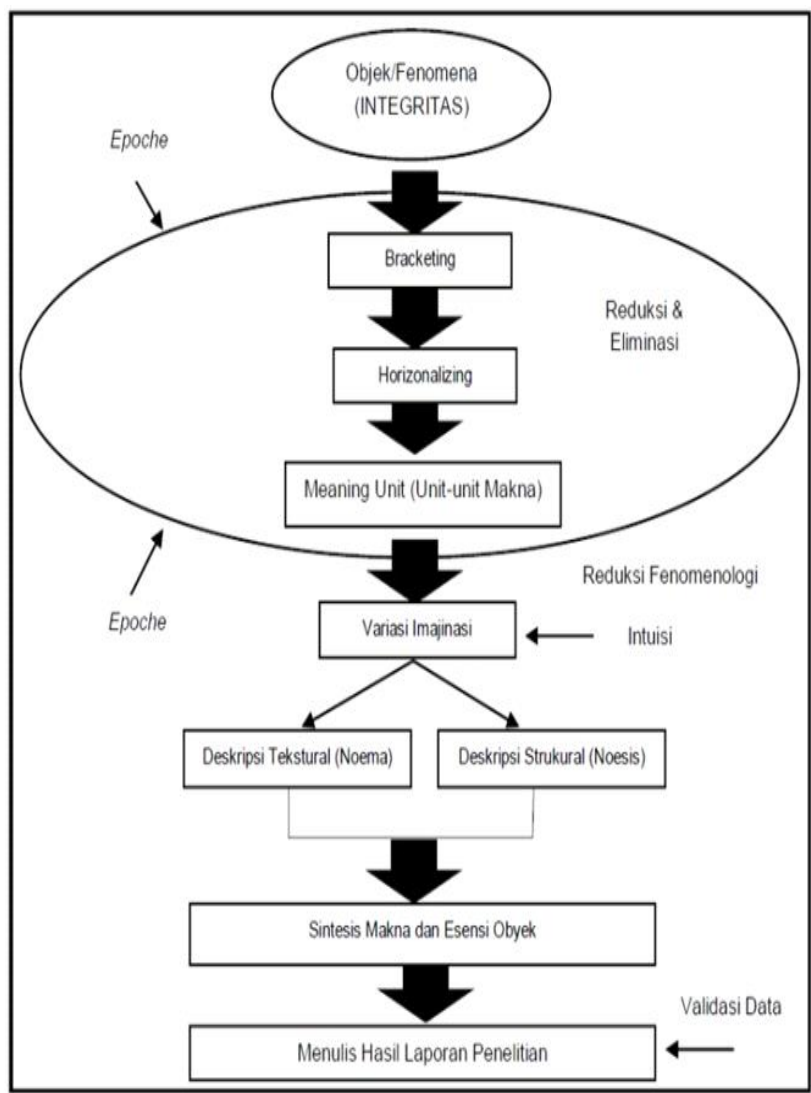

Gambar 1

Model Penelitian Fenomenologi

Sumber : Kuswarno, 2009:80 


\section{PEMBAHASAN}

\section{"Aku" dan "Akuntansi"}

"Aku" sebagai individu yang berbeda telah melalui pengalaman yang berbeda dalam membangun makna akuntansi. Proses pemberian makna akuntansi dan cara mempraktikkan akuntansi juga berbeda. Berdasarkan kesadaran Tumi memaknai akuntansi sebagai :

"Akuntansi yang aku pahami itu adalah ilmu yang mempelajari mengenai (perhitungan uang)"

Pernyataan awal (noema) Tumi sebagai informan yang memiliki latar belakang nonakuntansi (Antropologi) memaknai akuntansi sebagai disiplin ilmu yang penuh angka dan melibatkan transaksi dengan satuan mata uang. Namun, Tumi menyadari dalam pernyataan berikutnya (epoche) bahwa betapa pentingnya akuntansi untuk diaplikasikan dalam keseharian individu ataupun dalam rumah tangga karena setiap individu memiliki keuangan masing-masing dan dengan akuntansi, individu atau rumah tangga dapat memantau pemasukan dan pengeluaran sehingga dapat mengontrolnya.

"Akuntansi itu penting karena orang punya (keuangan masing-masing). mau itu perusahaan atau rumah tangga. Sedangkan pasti membutuhkan menghitung itu semua (berapa pemasukan pengeluaran), biar lebih (ketauan) aja perginya uang itu kemana.

Selanjutnya, pernyataan kesadaran Tumi menjadi Noesis yang muncul akibat pengalaman karena dan pada waktu dan tempat tertentu.

"Aku menerapkan akuntansi dalam hidupku, aku kan hidup (ngekos) sendiri dimana aku (ngitung) keuanganku setiap bulannya, gimana aku (ngatur) keuanganku kemana perginya uangku selama ini, gimana uang dari orang tua (bisa cukup) sebulan"

Intentional analysis menunjukkan bahwa sebagaimana pengalaman Tumi sebagai anak rantauan yang harus hidup sendiri membantu membentuk makna akuntansi dengan mempraktikkan akuntansi dalam kesehariannya untuk menata kebutuhan hidup selama periode waktu tertentu. Eidetic reduction dari studi fenomenologis dengan Tumi adalah Tumi memaknai akuntansi sebagai ilmu yang mempelajari mengenai perhitungan uang yang berguna untuk mengetahui pemasukan dan pengeluaran kas dengan tujuan untuk memudahkan dalam kontrol keuangan baik bagi individu maupun rumah tangga.

Selanjutnya, berdasarkan kesadaran Tumi memaknai akuntansi dalam rumah tangga sebagai:

"akuntansi penting apalagi untuk rumah tangga, buat ngitung dapetnya uangku berapa, untuk rumah tangga berapa, larinya uangku kemana, karena rumah tangga lebih (kompleks) kan ya."

Pernyataan awal (noema) Tumi memaknai akuntansi untuk rumah tangga sebagai alat rekam jejak yang berguna karena dalam akuntansi rumah tangga bersifat lebih kompleks. Pernyataan berikutnya (Epoche) menyatakan bahwa kekompleksan itu terjadi lantaran dari semula hidup sendiri kemudian hidup bersama pasangan yang merupakan "aku" yang berbeda.

"Kalau aku hidup sendiri kaya gini kan yaudah sih itu hidupku gitu meskipun cukup gak cukup ya risiko sendiri. Kalau rumah tangga kan kita hidup (berdua)."

Pernyataan berikut menjadi noesis :

"Belum lagi tambah lain lain lain pemasukan berapa keluar berapa kan (harus jelas) ya"

Intentional analysis menunjukkan bahwa sebagaimana pengalaman Tumi membentuk makna akuntansi rumah tangga lebih kompleks dibandingkan dengan pengaturan akuntansi untuk pribadi. Eidetic reduction dari studi fenomenologis dengan Tumi memaknai akuntansi rumah tangga sebagai alat rekam jejak yang membantu menyelesaikan masalah keuangan dan kerumitannya sehingga dapat tercipta transparansi dalam rumah tangga.

Beralih pada informan kedua yakni Mocha yang merupakan informan dengan latar belakang Akuntansi, membuat pernyataan awal (noema) dengan memaknai akuntansi sebagai kebutuhan hidup sehari-hari. Dalam pernyataan berikutnya (epoche). Mocha menyatakan bahwa akuntansi berguna dalam penentu dalam pengambilan keputusan dalam kehidupan sehari-hari. Noesis dari pernyataan Mocha adalah bahwa selama ini kita hidup berdampingan dengan Akuntansi.

"Akuntansi itu berlaku di kehidupan (seharihari)." (noema) 
"Dalam (mengambil keputusan) harus menimbang baik buruknya bagi diri kita. Nah itu termasuk salah satu perilaku akuntansi." (epoche)

"Akuntansi itu penting karena setelah saya dalami ternyata selama ini yang kita lakukan sehari-hari mulai kecil sampai dengan dewasa sebenernya ada akuntansinya. Tidak selalu menghitung dalam berupa angka, bisa juga berupa opsi"(noesis).

Intentional analysis menunjukkan bahwa sebagaimana pengalaman Mocha membentuk makna akuntansi yang diinternalisasi dalam keseharian. Eidetic reduction dari studi fenomenologis dengan Mocha adalah Mocha memaknai Akuntansi sebagai alat bantu dalam pengambilan keputusan sepanjang kita hidup mulai dari kecil hingga dewasa.

Dari pemaknaan yang telah didapat, dapat dipahami bahwa sudut pandang dalam pemaknaan akuntansi berbeda sesuai dengan kebutuhan masing-masing individu yang memiliki pengalaman berbeda. Dalam hal ini, Tumi sebagai lulusan disiplin ilmu Antropologi memiliki pandangan pemaknaan yang berbeda dari Mocha yang memiliki latar belakang Pendidikan Akuntansi. Tumi memaknai akuntansi sebagai alat bantu rekam jejak dalam mengontrol keuangan, sementara Mocha memandang akuntansi secara berbeda, yakni sebagai alat bantu dalam pengambilan keputusan sehari-hari.

\section{Jodohku dan Akuntansi}

Dalam pernyataan Tumi mengenai kriteria pasangan, dengan kesadarannya membentuk pemaknaan bahwa :

"Nanti pasanganku (minimal harus tau) cara (mengatur keuangan) lah.. tau berapa (pemasukan) dia, tau (estimasi) berapa (pengeluaran) dia setiap bulannya, harus tau dikit-dikit cara ngitung duit, keuangan dsb." (noema)

"Rumah tangga itu sistem ekonomi terkecil, disitu ada (perputaran ekonomi, pemasukan, pengeluaran) dsb kalau sama-sama nggak tau ngitungnya terus gimana.. nanti kalau samasama (gagal) di ekonominya ya susah..." (epoche)

"Masalahnya ya aku aja lemah dalam
Antara Aku, Jodohku dan Akuntansi (Selvia Eka Aristantin, Ade Irma Suryani Lating)

hitungan keuangan, lah nanti kalau misal aku cari pasangan yang sama-sama... hmmm (memutar mata) menghabiskan uang yang nggak tau kemana kan itu...suatu hal yg (mengerikan). Banyak keluarga yang hancur karena ekonominya (nggak bagus) dan mungkin itu karena pengaturan akuntansi yang jelek juga."(noesis)

Intentional analysis menunjukkan bahwa sebagaimana pengalaman Tumi membentuk makna akuntansi lebih dalam dengan membaurkan wujudnya dalam kriteria pasangan lantaran ia menyadari kurangnya kemampuan dan wawasannya dalam menghitung. Eidetic reduction dari studi fenomenologis dengan Tumi memaknai akuntansi sebagai tolak ukur kriteria pasangan sebagai partner untuk bekerjasama sehingga dapat menghindari 'rasa takut' akan kegagalan dalam berumah tangga. Selain itu, Tumi mengimajinasikan bahwa suaminya kelak adalah kepala rumah tangga yang juga akan memimpin dan mengatur keuangan bersama, sehingga pengetahuan akan akuntansi itu menjadi penting untuk dijadikan 'patokan' sebagai kriteria calon suami.

"Kalau misal ada cowok gak punya duit, dan dia gabisa ngatur itu kan dia itu aduh pantas untuk ditinggalkan..kalau misal dia punya tapi dia gak karuan boros juga enggak deh kayaknya,, karena yaaa ngatur duit sendiri aja gabisa gimana ngatur duit Bersama nanti kita jadi bangkrut bersama...jadi penting banget kriteria itu"

Pemaknaan tumi dalam menetapkan kemampuan Akuntansi sebagai salah satu kriteria pasangan tersebut dibentuk atas persepsi atas pengalaman serta persepsi bagaimana ia melihat lingkungan sekitarnya. Temuan ini mendukung pernyataan Triyuwono (2006) bahwa Akuntansi dapat dibentuk oleh lingkungannya dan sekaligus dapat membentuk lingkungannya. Berikut pernyataan-pernyataan Tumi yang penulis rasakan sebagai persepsi Tumi melihat lingkungannya.

Pengalaman A :

"Ada temenku yang dia sama-sama kerja nih ya.. tapi kenapa kok bisa nggak cukup sebulan? nggak cukup itu kemana gitu kan? Berarti dia gagal mengatur keuangan keluarganya. Tapi ada juga yang biasa aja standar penghasilannya, tapi kok mereka bisa 
sampek cepet beli rumah, cepet beli mobil, ekonominya stabil, gak mewah-mewah banget tapi kan cukup stabil berarti kan mereka pinter ngatur duitnya itu kan"

\section{Pengalaman B}

"Kalau pas masa pandemi ini temenku cerita bisnisnya ada yang kacau gak karuan dia gak punya simpenan disaat terkena kayak gini dia akhirnya kelabakan. Kayak gitu (kemampuan dalam akuntansi dan mengatur keuangan) keliatan di situasi kayak gini .."

\section{Pengalaman $\mathrm{C}$}

"Tetangga sekitarku ada yang jadi TKI dia gagal mengelola keuangannya. Dia keluar negeri dapat uang banyak (kemudian ditransfer ke suaminya di rumah). Tapi dirumah suaminya yg ditinggal ini gak pinter ngelola keuangan otomatis pas dia balik lagi ke Indonesia gak ada apa-apa. Habis..berasa sia-sia bertahun-tahun keluar negeri gak ada hasilnya"

Beralih pada informan kedua yakni Mocha yang merupakan informan dengan latar belakang Akuntansi, ia membuat pernyataan awal (noema) bahwa dalam membangun rumah tangga perlu ditetapkan kriteria tentang pasangan dan tentu ilmu akuntansi diperlukan sebagai bagian dalam pengambil keputusan.

"Dalam membangun rumah tangga kedepan penting sekali (menetapkan kriteria itu) apalagi di jaman sekarang harga rumah gabisa disebut nah kita harus pinter memanage kalau enggak gabisa punyak rumah beneran." (noema)

"Belajar akuntansi dalam memilih pasangan itu realistis karena tiap hari kita harus menghitung, menghitung dan menghitung. Apalagi di masa seperti ini... nanti kita itu udah harus planning. Nanti kalau pasanganku ini nanti (gaya hidupnya) kayak gini. Misal dia suka ngafe nah mau gak mau saya kan harus ikut ngafe, nggak bisa tiba-tiba aku nyuruh dia ayo dong nggak usah ngafe. Yaudah aku ngafe sendiri aja. Yg ada nanti baru berapa bulan cerai dong nah itu kan harus juga dipikirkan. Baru kemudian kita timbang lebih banyak baiknya atau tidak." (epoche)

"Saya jadi inget kata dosen saya waktu kelas akmen (akuntansi manajemen) kalian misal punya pacar pilihannya ada dua yang satu bibirnya lebar yang satu bibirnya tipis itu kan (costnya lebih besar yang lebar) karena mau gak mau gincunya lebih mahal. Terdengar lucu tapi bener juga karena itu kehidupan nyata"(noesis)

Intentional analysis menunjukkan bahwa sebagaimana pengalaman Mocha membentuk makna akuntansi lebih dalam yaitu dengan mengimplikasikan "mental accounting" dalam menetapkan kriteria calon istri. Eidetic reduction dari studi fenomenologis dengan Mocha memaknai akuntansi sebagai tolak ukur kriteria dalam menetapkan calon istri sebagai hal yang realistis untuk menghitung dan mengatur demi menetapkan rencana masa depan. Dengan rencana tersebut, Mocha juga menyamakan gaya hidup pengeluaran pasangan dengan standartnya untuk mencapai kebahagiaan.

"Hal kecil lainnya seperti (gaya hidup). Banyak cewek yang suka Boba (noema). Oh yaallah kalok misal dia konsumsinya kayak gini ya kau mau gimana ya... Karena (trend) mungkin ya..tapi gak semua wanita kayak gitu cuman kebanyakan (epoche). Nah disitu gunanya akuntansi....harus bisa (memilah) poin-poin mana yg menurut anda krusial dan memang benar-benar harus gakboleh (dibeli) iya ini gaboleh gabisa aku kl gitu.. mana yang lebih cocok buat kamu..sejauh mana kamu bisa mnerima kekurangan dia...."(noesis).

Intentional analysis menunjukkan bahwa sebagaimana pengalaman Mocha dalam bersosialisasi, membentuk makna akuntansi lebih dalam yaitu dengan mengimplikasikan "mental accounting" dalam menetapkan kriteria calon istri. Eidetic reduction dari studi fenomenologis dengan Mocha memaknai gaya hidup sebagai hal yang harus diperhitungkan dalam Akuntansi. Tren dapat mengkredit harta. Sehingga Akuntansi berguna untuk menetapkan apa yang menjadi skala prioritas dalam membuat keputusan. Sehingga, dengan begitu, Mocha merasa menjalani hidup dengan baik dan nyaman. Sebagaimana informan pertama, Mocha juga mendapatkan persepsi atas pengalaman yang telah dilalui tentang apa yang ia lihat, dengar dan rasakan dalam hidupnya. Berikut pernyataan dari informan.

Pengalaman A

"Contohnya saja ibu saya. Saya jadi cerita nih ya 
ibu saya dulu itu lulusannya SMP dan itu kalau belanja itu udah diamplopi satu-satu dijatah tiap hari gakboleh lebih dari itu... itukan sebenarnya udah akuntansi..akuntansi budgeting.. Kalau diamplop itu udah habis itu yaudah gakboleh. Nanti kalau pake amplop selanjutnya ya besok gak makan."

Selanjutnya, Mocha juga menyatakan bahwa ia tidak menyukai wanita yang suka keluyuran dalam noema nya lantaran hal tersebut akan membuat ia mengeluarkan uang (epoche). Mocha mengibaratkan seperti dalam Teori Bad Debt Expense dalam memilih pasangan (noesis).

"Nggak suka cewek yang keluyuran..karena keluyuran itu bikin belanja..karena saya sendiri kan rumahan.. bu selvi baru kluar rumah aja pasti uda kluar duit..starter motor aja itu uda kluar duit itu..." (noema)

"Misal aku ke tepe ah aku gak beli apa-apa. Cuma beli cinca*statio* kayak jaman-jaman kuliah...tapi dari situ sebenernya udah banyak biaya yang timbul. Kamu parkirnya berapa kamu bensinnya berapa blom lagi kalau diajakin temenmu ada diskonan ayok joinan..gitu.....tapi saya belum punya rencana mengatur pembagian penghasilan.. tapi yang jelas saya akan ngomongin itu sebelum menikah gak mau beli kucing dalam karung...meskipun..ada yang bilang sebaikbaiknya pasanganmu bakal kelihatan kalau uda menikah ya." (epoche).

"Gini ya..Kalau pake prinsip akuntansi lebih ke kayak yaudah siap-siap nanti bakal ada zonknya pasti kayak kalau di akuntansi prinsipnya bad debt expense.. ja di oh yaudah aku emang udah ngira kok bakal ada kejadian kayak gini..jadi sakit hatinya itu bakal separo .."(noesis).

Intentional analysis menunjukkan bahwa sebagaimana Mocha dalam membentuk makna akuntansi lebih dalam didasari dengan pengalaman bersosialisasi, gaya hidup dan tren dalam menetapkan kriteria calon istri. Eidetic reduction dari studi fenomenologis dengan Mocha memaknai penerapan akuntansi sebagai aktualisasi dari teori Bad debt expense dalam memilih calon istri agar dapat menghindari membeli kucing dalam karung.
Antara Aku, Jodohku dan Akuntansi (Selvia Eka Aristantin, Ade Irma Suryani Lating)

\section{Aku, Jodohku dan Akuntansi}

"Aku" sebagai simbol dari penekanan fenomenologi dengan kecenderungan melihat dari sisi "aku" dalam memaknai sesuatu. "Aku" dalam memilih "Jodohku" melibatkan unsur "Akuntansi" yang terpatri dalam pikiran dan hatiku. Dibayangi dengan pengalaman masalalu "Aku". Menjadikan Skeptitisme timbul dan meleburkan Mental Accounting dalam pilihan "Aku".

Akuntansi dimaknai sebagai ilmu yang mempelajari mengenai perhitungan uang. Akuntansi penting dipelajari untuk mengetahui darimana asalnya pemasukan dan kemana perginya pengeluaran kas dengan tujuan untuk memudahkan kontrol dalam keuangan baik bagi individu maupun rumah tangga. Akuntansi dalam rumah tangga dimaknai sebagai alat rekam jejak yang membantu menyelesaikan masalah keuangan dan kerumitannya sehingga dapat tercipta transparansi dalam rumah tangga. Transparansi keuangan dalam rumah tangga diperlukan untuk menjaga keharmonisan dalam rumah tangga. Rumah tangga terdiri dari sepasang suami dan istri yang memiliki dua kepala dan pemikiran yang berbeda. Memiliki kebutuhan dan kepentingan yang berbeda. Oleh karenanya diperlukan transparansi dalam pengelolaan keuangan atau dalam pengaturan pencatatan akuntansi rumah tangga.

Demi mewujudkan pengelolaan keuangan atau akuntansi rumah tangga yang baik, diperlukan suatu tolak ukur, yakni pasangan itu sendiri. Pasangan yang memiliki pengetahuan akuntansi, memiliki wawasan akuntansi, serta mampu berkolaborasi dalam mewujudkan akuntansi yang baik dalam rumah tangga. Makna akuntansi disini sebagai tolak ukur kriteria pasangan sebagai partner untuk bekerjasama sehingga dapat menghindari 'rasa takut' akan kegagalan dalam berumah tangga. Selain itu, Kepala rumah tangga memiliki peran yang kompleks. Kepala rumah tangga akan memimpin, mencari serta mengatur keuangan bersama, sehingga pengetahuan akan akuntansi itu menjadi penting untuk dijadikan 'patokan' sebagai kriteria calon pasangan.

Akuntansi juga dimaknai sebagai alat bantu dalam pengambilan keputusan. Bukan hanya keputusan dalam ukuran angka ataupun nominal, namun dalam bentuk opsi. Pilihan-pilahan yang datang di sepanjang hidup mulai dari kecil hingga dewasa. Akuntansi dimaknai sebagai tolak ukur realistis dalam menetapkan kriteria teman hidup. 
Merupakan hal yang realistis untuk mempelajari dan mengerti akuntansi untuk belajar menghitung dan mengatur dan menetapkan rencana masa depan. Dengan rencana tersebut, seseorang dapat memperkirakan pengeluaran, menemukan pasangan dan memasang gaya hidup yang sesuai dengan standart pendapatan untuk mencapai kebahagiaan. Gaya hidup merupakan salah satu hal yang harus diperhitungkan dalam Akuntansi. Gaya hidup dapat dipengaruhi oleh Tren. Oleh karena itu, Tren dapat mengkredit harta dan jika terus menerus dilakukan tanpa perhitungan, bukan mustahil akan menggerus kekayaan. Sehingga dalam memilih teman hidup yang mengerti tentang ilmu akuntansi memberi standar untuk menyamakan kebiasaan dan gaya hidup sehingga mendapatkan ketenangan dalam mengarungi bahtera rumah tangga. Akuntansi dimaknai sebagai bentuk dari skala prioritas dalam membuat keputusan. Sehingga, dengannya dapat menjalani hidup dengan baik dan nyaman.

Salah satu responden bahkan melakukan aktualisasi mental accounting dengan menerapkan teori Bad debt expense dalam memilih jodoh agar dapat menghindari membeli kucing dalam karung. Bad debt expense merupakan piutang yang disangsikan atau diragukan penerimaannya karena kegagalan usaha atau memang merupakan suatu kesengajaan debitur tidak membayarnya. Untung menghindari rugi berlebihan, seseorang dapat mengalokasikan piutang untuk berjaga-jaga jika debitur tidak membayar. Sama halnya dalam memilih jodoh. Jangan sampai membeli sesuatu tanpa melihat barangnya. Jangan sampai memilih jodoh tanpa mengenalnya. Jangan sampai Memilih calon pasangan tanpa menyatukan persepsi keuangan sebelum menikah. Meskipun setiap manusia terdapat kekurangan, dengan menetapkan kriteria tersebut. Setidaknya kita berjaga-jaga agar terhindar dari kegagalan dalam berumahtangga.

\section{PENUTUP}

\section{Kesimpulan}

Dari hasil yang diperoleh dari penelitian ini dapat disimpulkan bahwa Akuntansi dimaknai sebagai alat bantu rekam jejak dalam mengontrol keuangan sekaligus sebagai alat dalam pengambilan keputusan sehari-hari. Kemajuan teknologi dan berkembangnya social media menjadikan ilmu akuntansi semakin menarik untuk dipelajari berbagai kalangan terutama generasi milenial. Anak muda semakin 'aware' dengan masalah keuangan, bahkan memaknai Ilmu Akuntansi sebagai tolak ukur kriteria yang dalam memilih jodoh untuk membentuk rumah tangga yang harmonis. Akuntansi dimaknai sebagai bentuk dari skala prioritas dan aktualisasi mental accounting dengan penerapan bad debt expense dalam memilih jodoh "Aku".

\section{Keterbatasan Dan Rekomendasi Untuk Penelitian Selanjutnya}

Penelitian dilakukan saat pandemic Covid-19 sehingga terdapat keterbatasan dalam tatap muka antara peneliti dengan informan, namun hal ini tidak mengurangi kualitas dalam hasil penelitian. Disarankan untuk penelitian selanjutnya agar dapat memperbanyak varian dari informan serta dapat mengaitkan dengan bidang studi lain misal psikologi atau agama. Sehingga, dengan adanya multiparadigma khasanah ilmu pengetahuan akuntansi dapat semakin luas dan berkembang.

\section{DAFTAR PUSTAKA}

Husserl, E. (1983). Ideas Pertaining to a Pure Phenomenology and to a Phenomenological Philosophy, First Book. Fred Kersten (The Hague:Martinus Nijhoff, 1983), 146.

Jatmika, Lia dan Esti (2018). Refleksi Nilai Filosofis Cinta Ditinjau Dari Sudut Pandang Akuntansi Sebagai Pencegahan Kasus Perceraian Sejak Dini. Seminar Nasional Pendidikan

Kamayanti, Ari. (2017). Metodologi Penelitian Kualitatif Akuntansi. Jakarta:Yayasan Rumah Peneleh

Kuswarno, E. (2009). Fenomenologi, Konsepsi, Pedoman dan Contoh Penelitian. Widya Padjadjaran. Bandung.

Suharsono dan Iwan (2020). Akuntansi Utang. Malang : Penerbit Peneleh

Triyuwono (2006). Akuntansi Syariah : Perspektif Methodologi dan Teori. Jakarta:PT Raja Grafindo Persada. 